\title{
Student Protagonism: the Use of Webquest as a Methodological Strategy in Teaching History
}

Luiz Carlos Ferraz Manini

Alessandra Dedeco Furtado Rossetto

Colégio Interativa Londrina

\begin{abstract}
The teaching of history is strongly marked by the concern of building, beyond the factual knowledge, a critical conscience in the students. Alongside this, we live in a reality marked by the intense information flow, available through the new information technologies, particularly the internet. In this way, the following problem arises: how to combine this great amount of information with the construction of a critical conscience, based on reliable information? The present case study searches through the use of WebQuests, a strategy that favors the teaching-learning relationship, to support the development of reflection and criticism of both the teacher and the student. Since it allows the teacher to select the resources available in the world-wide web, being able to make possible the contact with instructional materials to the research group involved in this case, students of the second grade of the High School. I selected those that will in fact contribute to the construction of a trustworthy knowledge that stimulates the critical sense when comparing diverse sources and materials, in the midst of an active learning process. According to this teaching-learning perspective, teachers are no longer the main knowledge depository and become methodological consultants and mediators of knowledge. The research is defined as a descriptive and analytical qualitative study, based on a private school in the city of Londrina (Brazil). As a result, it will be verified if the students, after the use of WebQuests, understand the importance of conducting research in so-called trusted places, in addition to perceiving the contributions of the WebQuest in the classroom, validating it.
\end{abstract}

Keywords: Teaching-learning process, WebQuests, History

\section{Introduction}

Thinking about teaching nowadays requires searching for new alternatives to a very complex picture: in the midst of the great transformation brought about by the new communication and information technologies, how can the teacher make his class more meaningful, bringing the student to greater participation and making the educating agent builder of your knowledge? It is based on the premise that it is possible and necessary to combine such technologies with the teachinglearning process, and the present work reports and analyzes an experience made with the use of WebQuest in History classes. As a result, it will be verified if the students, after use, understand the importance of conducting research in socalled trusted places, in addition to perceiving the contributions of WebQuest in the classroom, validating it.

\section{Thinking the teaching of History}

Reflecting on how to give the teaching of a subject, through its theoretical and methodological requirements, as well as the objectives that must be achieved in the middle of the educational process of the school, of which the present work is concerned, demands a consideration, even though it's quite brief, of his own course as a science. Particularly in the case of History, which implies, like other human sciences, in a critical formation of the student, one must be aware of how this subject was conceived as a science, perceiving the necessity of the moment of its establishment and its objectives.

It can be said that the gain of a scientific status of the study of History in Brazil occurred in the first half of the nineteenth century. Brazil, made independent of Portugal in 1822, passed in this period by a great discussion in the intellectual circles about the formation of the nation. Much has been discussed, even in a very aggressive way, in the sense of understanding and, moreover, presenting projects on how Brazil should organize itself after more than three hundred years as a colony. 
Initially, after the fall of the official censorship in 1821, such a debate gained prominence through the pages of the newspapers, a means of communication that was spreading strongly in the country at that moment and that was able to cover the most different political conceptions, ranging from a radical liberalism to the defense of a concentration of total power in the hands of the emperor Pedro I.

This discussion went through all the First Empire (1822 - 1831) and advanced, with mitigated power, through the Regencial Period (1831 - 1840) when deputies exercised their power in the name of Emperor Pedro II, still not old enough to take political control of the country. There have been a huge number of debates that have taken place in what was the most turbulent political period in the country's history, which saw the outbreak of several revolts that seriously endangered the Brazilian territorial unit. It was during this period that in 1838 the Brazilian Historical and Geographical Institute (IHGB) was established in Brazil, an institution designed to write an official history of the nation and to establish, in the midst of the various political and social conflicts that were taking place at that moment, the definitive image about what should be Brazil.

Paulo Knauss and Temístocles Cezar, in preface to the work of Manoel Luiz Salgado Guimarães, explain the importance that the writing of history gained at that moment, when postulating that,

"The process of constructing the idea of a Brazilian nation must be understood as an 'authentic state project', in which the literate elite and state agents (who, in most cases, became mingled) mobilized a series of political, economic, cultural and symbolic resources at the service of its creation" (2011, p. 12)

This image of the Brazilian nation, to be consolidated by the action of the Institute and its affiliates, would have the purpose of showing a united nation, composed by the presence of the "three races", as an event that, present in the past, could and should be taken as an example for the present and model for the future. Through the image of the union, it was sought to decompose the legitimacy of the movements that opposed the government and its mode of action. This ideological premise of the nation was sustained, throughout the Second Brazilian Empire (1840 - 1889), through the basis of the Romantic movement, which in Brazil gained some different contours of its European counterpart. According to Bernardo Ricupero (2004), Brazilian Romanticism "considers that the main characteristics of the Brazilian nation would be in the exuberant American nature, and in its original inhabitant, the Indian" (p. XXVIII). In the same way, while European romanticism was a reaction to the advance of capitalism and new social relations initiated there, in the Brazilian case such an economic and social system was viewed with sympathy, although there was a widespread fear about the slave, which explains, still according to Ricupero, that the black people almost does not appear the beginning of Romanticism.

Thus, it is understood that the initial objective of the study of history in Brazil was to build a nationalism that, starting from a concern of the State regarding to the political-social situation of the country, served as an agglutinating element of the population gathered here. Allied to this, the political measures taken by the emperor, along with the economic growth caused by the expansion of the coffee plantations, have made the country go through a stability that has extended for more than three decades. It was in the 1880s that a series of conflicts between political power, the Church and the military led to a seizure of power by the Army and the end of imperial government in Brazil.

Once the republican government has initiated, little changed in the understanding of what history would be and what its role in the formation of citizens. This discipline was understood as forming a patriotic feeling, based on the action of the great men of the government, in a perspective strongly aligned with positivism. Some changes have been felt, particularly with regard to the icons around which history should align. Circe Bittencourt (2011) points out that "the image of Tiradentes, recovered by the military at the end of the 19th century, began to become a national symbol, seeking to recall the event associating republic and freedom" (p. 73). However, as new heroes were listed and if one sought to associate civic rituals with historical remembrance with a militaristic tradition, there were no substantial changes in the interpretation of the meaning of history, or even of its form of teaching.

More significant transformations in the understanding of Brazil's past appeared in the 1930s, when Getúlio Vargas became the country's ruler. It was a time of changes from the economic point of view, with the effective beginning of national industrialization, as well as of social changes, with the increase of the working mass that came to live in the cities. The intellectuals of that time, checking the changes that took place, sought to understand the reason for the national "backwardness", in view of the other nations already industrialized and economically advanced. However, little criticism was the story still produced and thought, based on the premise of miscegenation as a constructor of Brazilian nationality, 
whose most striking feature was its pacifism and tranquility. But this situation would change, such as taught Jaime Pinsky (2011),

"In the late 1950s, and even more so, in the early 1960s, concern for the sciences of society has expanded greatly. It was the time of the 'grassroots reforms', changes demanded by workers, students and middle-class sectors in order to modernize and democratize the country's wealth division" (p. 20).

These decades marked the beginning of the popular classes' access to formal education, particularly through the creation of night courses, which should serve to create a more qualified proletariat that could serve to occupy the jobs in the industries that spread in Brazil. Despite such a technicist view, advances were seen in the interpretation of history, with more emphasis on the study of the black people's condition and the history of their exploitation in Brazil. Many scholars appropriated Marxism at that moment and started to rewrite history from the objective material conditions to which the workers of the country were subjected.

However, such a change in the historical interpretation of Brazil was soon inhibited by the rise of the military to power in 1964. In a period characterized by the intense ideological dispute of the Cold War, it was up to the Brazilians, in line with US interests, to put away the socialist danger that was alleged to surround the government. To this end, the military took power to remove João Goulart from presidence, under the allegation of building a government with socialist characteristics. In this context, teaching was hard hit, and the changes that could have shifted from academic analysis to basic education were thwarted, with the permanence of a history seen as linear, progressive, "stories of kings, heroes, and battles, which reduced men to the category of tiny object in the universe of grandiose monsters that decide the path of humanity and the role of each of us, mere mortals "(Pinsky, 2011, 21). Reinforcing nationalism, such a view of history was still aligned with a notion of "banking knowledge", as Paulo Freire (2002, p. 13) would define, that is, a notion that the student would merely be the depository of knowledge to be there deposited by the educator.

However, this was not just a time of setbacks. There has been, though timidly, some advances, as Circe Bittencourt (2008) points out

"Criticism of teaching methods led educators in the late 1960s to put more emphasis on this aspect, and the renewal of teaching thus fell on methodological issues. The emphasis on the need for methodological renewal favored the emergence of proposals that separated teaching methods from explicit content "(p. 225).

Although the contents were at the moment in the service of the construction of a nationalistic imaginary, at least there was a concern about the "how to teach", more profitable than that concerning "what to teach". From this context, the use of, for example, audiovisual resources for the teaching of the humanities, since such an instrument would allow the understanding of a story not only narrated, but perceived as made by people who, in the midst of films and images projected, gained materiality. This appeal to the use of films and documentaries became productive also by allowing different readings about a given event to be confronted by the students. As Abud, Silva and Alves (2010) affirm, "if conceptions of the past are products of the present, films reveal in their interior interpretations that, contrary to historical knowledge created through research, different visions about the same facts "(p. 167). According to Bittencourt (2008), "directed studies, crossword puzzles and other word games corresponded to mnemonic techniques understood as 'innovative teaching methods'" ( $p$. 226).

This renewal, although discreet, expanded in the 1980s, when the military regime established in the country began to lose its force and democratic openness began to impose itself as a necessity, since the so-called "socialist danger" was already gone away, the economic crisis and the denunciations of violence against civilians removed the legitimacy of the Armed Forces as political leaders. From 1985, with the election of Tancredo Neves, the country once again had a civil government, and political reorganization measures began to emerge, giving voice to several groups that couldn't manifest themselves until then. Their demands began to gain materiality with the Constituent Assembly which, in 1988, enacted a constitution quite advanced for the time in terms of social rights.

In the midst of this process, educational reforms have also gained momentum, both in the sense of renewing curriculum content and in regard to methodologies, since, "the teaching process is intrinsically linked to the social process and the modifications in one of them reflect and are reflected in the other "(Horn, Germinari, 2006, p.18). The advance of democracy, giving voice to many groups that were previously invisibilized, made it necessary to rethink both the content to 
be apprehended by the students and how to get the student to get in touch with this knowledge, that is, it was sought a renewal that covered not only the curriculum but also the methodology used in the classes.

Circe Bittencourt (2008) also warns in this regard that the educator should have clear in his practice what is understood by "teaching methodology" (p. 226), since it differs from what can only be called "teaching technique ". By teaching methodology can be understood a set of techniques whose execution is linked to the fulfillment of a specific pedagogical proposal, which pervades all instances of learning within an institution. Not just the execution of a lesson, but anything that can favor learning can and should be contemplated by this methodology. As for the teaching technique, it can be defined as a specific strategy, within which many different resources can be used, and whose objective will always be student learning.

In this way, it is not assumed that the use of a technique has value in itself, but that it is inserted in a process that crosses all the performance of the teacher and the very operation of the institution in which this educator is inserted.

Thus, we are living today in the wake of the transformations begun in the $1980 \mathrm{~s}$, permeated by one more fundamental element: the advent of the internet and the immense diffusion of information technologies. These have provided unprecedented access to information, which can be thought of both as an ally and as a constraint in the teaching-learning process. Allied in the sense that information now is all available online, since previously it would require long journeys to libraries or documentation centers and would require, either from the teacher or from the student, a great deal of work in locating, manipulating and finally acquiring such information, through books and documents present in such institutions. However, while facilitating access to information, such technologies make available to those who want to research a given subject a torrent of information whose truthfulness may be challenged, or that brings errors that, although small, can contribute to the construction of a distorted vision of certain subjects.

In this way, thinking about the use of the internet and its resources in the classroom is fundamental for the history professional, given the immense amount of sources, diverse documents and supporting texts that can be used in the teaching process. However, there is a constant struggle in this direction: many educators, in their lines or even in their writings, seem to be fully aware of the need for new methodologies that take on greater student protagonism, and even accept that the Internet can be a facilitator of this process. However, by actually putting their work into practice, these same educators maintain a more traditional class perspective, in the form of an expository class, without giving space for an effective participation of the student. Jaime Pinsky (2011) in a text that discusses the importance of history, points out this same incoherence when talking about a history understood only as "science of the past". In the words of the historian, "This conception of history, although much criticized 'in thesis' and resulting in jokes, is still used in practice by many historians, authors and professors, for whom to historicize is simply to report something that is already behind" (p. 9)

It is necessary, at a practical level, for a greater knowledge and even validation of these new methodologies so that, effectively, these changes that have been thought over the last three decades leave the level of the theory and reach its fullness as practice, so that the student cease to be treated as a receiver of ready knowledge and become himself the constructor of such ideas. According to Paulo Miceli, this

"can begin with what would be the reversal of a puzzle: the ready and finished event, which always composes an image that aspires to encompass the totality, must be decomposed to denounce viewers to the arbitrariness of their construct, as if one were showing the audience to the invisible threads that support the tricks of the illusionist - as supernatural as any of us" (2011, p. 45).

In a society in which the advancement of information technologies is inexorable, it is up to the educators to know and apply in their practice methodologies that allow the student to elaborate their knowledge. This does not mean that the teacher becomes expendable; on the contrary, its performance is of fundamental importance, but not as absolute holder of knowledge, but rather as mediator in this process of teaching and learning. In this process of mediation, many tools have been developed and applied effectively, showing that change is possible without the need for an absolute rupture, which could lead to the confrontation of the teachers with the new technologies and, therefore, put them away from this required transformation. The use of the WebQuest tool has become, more and more, an allied to the teachers in their classes and of course, in the history classes it could not be different, even going in the direction to allow the supervised autonomy of the students. To understand it in its importance and scope, it is necessary to understand that it forms part of the set known as active teaching-learning methodologies. 


\section{The active teaching-learning methodologies}

We're living right now in a time of extreme technological development. The school of today requires changes in the posture of those involved in the teaching and learning process in order to favor the quality of the classes, as well as the teaching strategies, which support the reflection and criticism development of both the teacher and the student. The changes in the way of teaching and learning started happening since Information and Communication Technologies (ICT) began to integrate the activities in the classrooms. The technologies have allowed new enchantment in the school, opening their networks for students to interact and exchange experiences with other students from different places, countries or different realities.

"Students and teachers find numerous electronic libraries, online magazines, with many texts, images and sounds, which make it easier to prepare classes, do research and have attractive materials for presentation. The teacher may be closer to the student. You can receive messages with questions, you can pass on additional information to certain students. You can tailor your class to the pace of each student. The teaching-learning process can thus gain dynamism, innovation and unusual communication power". (Moran, 1995, p.25)

In this context it is necessary to situate some questions related to the objectives of the new technologies in the educational context. According to Barreto (2002), new technologies are those that are not confused with "old" ones: blackboard, notebook, pencil, pen, textbooks, etc. Such new technologies are information and communication technologies (ICT), in a formulation that demarcates their belonging to non-educational areas, in the sense of produced in the context of other social relations for other purposes.

The use of resources related to new information and communication technologies (ICT), such as simulators, virtual reality, mobile devices and even the simple use of cyberspace, has established itself as a new moment in the educational process. The flow and speed of network interactions and the collaborative purpose of information show a growing need for building new educational structures. Students no longer want to be passive in front of a television for example; his acting happens instantly via Twitter or sharing in networks like story of Instagram, Facebook or Snapchat. How to deal with this student in the classroom? According to Kenski (2012),

"The linear articulation of the classroom, in which the teacher only speaks, and then responds to the students' questions, does not always produce expected results. The students, especially the younger ones, scatter and start zapping in class. Their attention oscillates between the teacher's speech, the behavior of colleagues, the noises; they travel in thoughts" ( $p$. 54)

According to Lévy (2007, p. 4), new ways of thinking and living are being elaborated in the world of telecommunications and information technology and with the range of technological devices and options to be worked in the classroom, the pedagogical and methodological practice of the teacher has to reinvent itself, becoming a constant awakening of new interests. It is no longer enough to change the chalk by the electronic board, the PowerPoint slides by the mirroring of digital didactic sequences, it is necessary to go beyond the universe of the classroom, to cross the walls of the school and to analyze, to punctuate the challenges, to discover the advantages and disadvantages of use of mobile technologies in virtual learning environments, since they are planned or incorporated in order to facilitate, support and extend the process of teaching learning inside and outside the school environment. In this way, the teacher becomes the moderator of the knowledge that the student will find in the different networks for pedagogical purposes.

\section{WebQuest as a teaching-learning proposal}

WebQuest is in line with proposals that have collaborative learning as a principle, since it is characterized by the active participation of the student in the learning process; by the mediation by teachers; by the collective construction of knowledge, the exchange between peers, the students' practical activities, their reflections, their debates and questions; by the interactivity between the different actors that act in the construction of knowledge; stimulation of expression and communication processes; development and evaluation of activities; the development of student autonomy in the teachinglearning process; the valuing of freedom with responsibility; commitment to authorship; by the valorization of the process and not of the product. According to Dodge (1995), the WebQuests are based on the conviction that we learn more and better with others, not individually. More significant learning is the result of acts of cooperation. 
In addition, surfing the Internet is accessing a universe of information; is to favor the integration of interactive collaboration groups at any time or place - a factor that makes it different from any other technological innovation that has emerged in recent times and that has been leveraging Distance Education. Silva (2000) points out that the internet becomes a valuable repository for the search of information if used in the construction of knowledge, generating a rich interactive and motivating learning environment. In the same way, it can also be a distracting element of data collection without relevance or that do not add pedagogical quality to the designated use.

For this purpose, a methodological intervention of using Webquest in a History class is presented here. The objectives of this study are to present to High School students the use of active methodologies during History class focusing on the content about the transference of the Portuguese royal family to Brazil in 1808 and the consequences of D. João Vl's government for the future of the country. In the context of historical learning about Brazil, using Webquest as a technological tool, it was sought to make the student understand the importance of the transfer of the Portuguese royal family as a decisive event for the independence of the country and its construction as a free nation.

According to Rocha (2007), the creation of the concept of Webquest arose from the need to make learners active agents of the teaching-learning process, removing from the teacher the image of the only source of knowledge in the classroom. In this way, Webquest has a structure that includes seven topics, defined by Abar and Barbosa (2008, p.21-35):

Introduction: briefly presents the subject and proposes questions that will base the evaluation process. It is the moment to arouse the students' curiosity in relation to the proposed theme.

Task: The task triggers a series of actions, about what to do. One should clearly propose the development of a creative product that will excite, motivate, and challenge students.

Process: describes how the task will be developed by the students and guides them in the information that needs to be present in the Process and in the Resources. The process describes step-by-step the activity dynamics, and the resources are information that allows you to complete the task.

Resources: in this section, the teacher provides students with the materials, previously selected on the internet, which can guide their study process. It is the moment of greater action of the educator, because it is up to him to choose which are the reliable sources that will guide the student through their work.

Evaluation: It must be presented to students with clarity how the outcome of the Task will be assessed and what factors will be considered indicative that it has been successfully completed. These criteria should be in accordance with your goals.

Conclusion: The conclusion sums up the purpose of what will be learned and signals how the student can begin to study the subject. It should be an invitation to learn more.

Credits: references to the authors of Webquest, to the school where it was elaborated, education level or age group to whom it is intended, the making or updating and other information that may be useful to those who are using it.

According to the authors, the structure proposed above validates the proposal of an activity which has the characteristics of research in which, first, the student will become aware of the subject matter; then the objectives are defined; the plan of the actions that must be executed is made; and present the resources and sources necessary to carry out the actions, and finally present an object of study that will subsidize the evaluation process.

The structure of the Webquest used for the History class was discussed among the authors so that the students could follow according to the evaluative process that would be established there, since it was an activity to which the students must have access to Internet sites, previously designated by the authors to, from this point on, be able to execute it autonomously. The following is the model developed for this methodological proposal for the History class.

\section{Applying the Webquest}

The subject chosen was the transfer of the Portuguese royal family to Brazil in 1808 and the consequences of D. João VI's government for the future of the country. As Laurentino Gomes points out, such an event 
"Occurred in one of the most exciting and revolutionary moments in Brazil and Portugal, where groups of such diverse interests as monarchists, republicans, federalists, separatists, abolitionists, traffickers and slave masters were opposed in a struggle for power that was to change radically the history of these two countries " $(2007$, p.20).

Among the various changes that are pointed out by the author, it may be noted that the government of $D$. João $V I$ was responsible for breaking the Colonial Pact, by determining in January 1808, upon arrival in the country, the Opening of the Ports to the Friendly Nations. By allowing Brazil to trade with any nation that was not considered an enemy, since the old metropolis was occupied by Napoleon Bonaparte's forces, the king ended the most characteristic measure of the entire Colonial System, namely, the restriction of trade.

It can also be argued that this transfer was responsible for the creation of an urban and administrative infrastructure that the country did not have until then, given its colony position. Due to the need to organize and administer the Portuguese Empire, whose headquarters were in Rio de Janeiro, several government agencies and departments were created, among them the Royal Printing. This agency was responsible for the rupture with the lack of printed letters in Brazil, giving rise even to journalism in the country, a channel of communication through which there would be numerous political discussions.

But not only of creations and positive aspects has been marked the administration of $D$. João in America. In 1817, a great revolt, caused by poverty, droughts and high taxes, took place in the province of Pernambuco, questioning the government of Rio de Janeiro and seeking separation from Brazil. This Revolução Pernambucana was the most serious protest movement to the power of the king installed in the old colony until 1820, when, in Portugal, the Revolução do Porto began. This movement, fueled by Portuguese dissatisfaction with the absence of the king and his insistence on not returning to the country, even after the determinations of the Congress of Vienna, forced the monarch to return under penalty of losing his throne. In addition, the king was obliged to swear a constitution which was drawn up by these deputies, meeting in Lisbon, and who wished to limit his power so that other situations such as this did not happen again. Finally, this Revolution also sought to annul the advances that had been won in Brazil, with the intention of recolonizing the country, subjecting it again to the exploration that had characterized the last three centuries. It is from this perspective that in 1822 the movement led by D. Pedro led Brazil to gain its independence and become a free nation.

This brief introduction, regarding the subject addressed by the students in contact with WebQuest, is necessary for the understanding of the importance taken by such historical event in the development of the country. The history of Brazil at the beginning of the nineteenth century is the history of the achievements of D. João VI's government or its consequences, and the country's political emancipation was deeply linked to this event. Therefore, it is essential for students, when studying the emergence of Brazil as an independent nation, to understand this event as part of a larger process than that which occurred in 1822.

Based on the perception of such importance, some topics were selected to be studied by students. Firstly, we sought to situate the event of the transfer of the Portuguese royal family to Brazil within the European context of the late Eighteenth and early Nineteenth century, when the advance of the Napoleonic troops across Europe forced such a change. For this, a video, approximately two minutes, was selected on YouTube and staged by well known actors to the Brazilian public. This video explained the performance of Napoleon Bonaparte within Europe and why the Portuguese court moved to Brazil. This content was complemented with the reading of an article published by a magazine specialized in producing contents regarding History for the public unfamiliar with historical researches.

Secondly, a collection of images, avaliable in an important news portal, was presented to the students, showing paintings depicting the main characters involved in such an event. The aim was to make concrete the figures that the students only heard or read about. Then, two other links led the students to have an overview of the process of installing the royal family in Brazil, showing the transformations brought by it. In this sense, two other links still guided the student by reading about the Opening of the Ports and the emergence of the press, points of outstanding relevance to subsequent events.

The students were then able to read about the protest movement that developed in Pernambuco, as well as about the Revolução do Porto, which constituted two more elements present in the resources available to students. Finally, the last link took the students to a set of four short videos, produced by Laurentino Gomes, which present an overview of such changes and their consequences for the independence of the country.

All of these materials whose links were made available through WebQuest provided students with a very broad view of the process we wanted to present. In addition, students were also instructed to use their textbooks if they felt it necessary to 
supplement or clarify any question, just as research on other internet sites was also encouraged. For this research, the time of one class (70 minutes) was made available, and students could finish these readings at home. In the possession of such information, students should then produce other materials that would translate into their evaluation. Two were the productions requested from students: first, students should construct, in their notebooks, a conceptual map in their notebooks about the transfer of the Portuguese royal family and the government of $\mathrm{D}$. João VI in Brazil. This strategy was used so that, through the materials consulted, the students could construct a diagram in which, by relating the concepts, they could also hierarchize the ideas and organize the studied content. This first assessment was proposed to students to be held collaboratively, although each student should have his own conceptual map in his notebook. This was assessed by the teacher through a resumption with the students and construction of the conceptual map in the board, from the information that was provided by the students.

Secondly, students were asked to produce, within a week, a video, lasting between five and eight minutes, illustrating the studied subject. Unlike the conceptual map, which would be in the students' possession and would serve for their particular consultation and study, the video would allow the teacher to evaluate the understanding that the students obtained at the end of this process. Students were instructed to freely produce the videos, using their creativity to expose the process that had been studied. In the following week, the videos were presented in the classroom, for the exhibition of the whole class and the authors involved in this work. Various strategies were used by the students, such as the presentation in the form of television news, stop-motion video or even in the form of interviews. The videos showed that, after reading, drawing up the concept map and taking it back in class, the students had appropriated such content, building in a mediated way the desired knowledge about such subject.

Lastly, students were offered a self-assessment, which sought to understand aspects such as: if students consider the Internet as a source of information and knowledge; if they understand the importance of using WebQuest in the classroom; if they believe that the knowledge building should start from the student; if they feel comfortable in relation to collaborative work and if they believe that the teacher should act as mediator in the teaching-learning process. These questions were presented to be evaluated according to the following gradations: "I fully agree", "I partially agree", "I cannot opine", "I partially disagree" and "I strongly disagree". One last question left some blank space for students to freely comment on their practice or use of the Internet as a source of research. The form was presented to students without the need for individual identification, which would allow them greater freedom when formulating observations about the use of the tool or the technologies in general. The data were collected using an online form, using Google Form, and the result of this selfassessment, as well as other considerations regarding the whole process are presented in the following section.

\section{Final Considerations}

The WebQuest whose application is discussed in this work was developed with a group of 18 students from the second year of High School of a private school in the city of Londrina (PR). $100 \%$ of the students participated in the proposal presented for the history class and answered the self assessment questionnaire that subsidizes the analysis and discussion of the validation of the tool as an instrument of the teaching-learning process. Once the data were gathered, we came to results that corroborate the thesis of the need for new methodologies that bring the student to an effective participation in their learning, confirming that WebQuest as a technological tool offers the students the opportunity to be protagonists of their learning, enabling the development of initiative and autonomy.

In the first question asked in this self-assessment, when asked whether they considered the Internet to be a relevant source of information and knowledge, $66,7 \%$ indicated the answer "I fully agree", while another $33.3 \%$ stated that "I agree partially." This can be understood from answers presented by the students themselves in the last section, when, among 10 answers in this particular item, 7 pointed out that the internet can be a great ally in the teaching and learning process, but that there must be, at the same time, great care in selecting reliable sources for this study. The participants of the research, adherents to the technologies that today invade reality, realize that these can and should be used to realize or reinforce their learning.

In the second question, when asked if they considered WebQuest as an important tool for classroom use, $77.8 \%$ of the students answered that they agreed partially, $16.7 \%$ showed that they fully agreed, while only $5.5 \%$ couldn't opine. The fact that $94.5 \%$ agree, even if partially can be analyzed from the perspective that the use of this resource should be seen as one more element in the process of teaching and learning, since multiple are the forms of learning, via active methodologies and the insistence on only one way of elaborating this process may not encompass the multiplicity of learning styles presented by students. 
In the third question, students should respond if they believed that the construction of knowledge should begin with the learner. $55.6 \%$ of the students agreed partially with this idea, $33.3 \%$ fully agreed with this, while $11.1 \%$ stated that they did not know how to express their opinion. It is perceived, through this question, that the students' posture meets the new pedagogical perspectives that place the learner as protagonist in their learning. Although still somewhat insecure, students realize that it is their responsibility to seek such a construction, since meaningful learning will occur as soon as they engage in such a process.

In the fourth question the students were asked if they felt comfortable about doing collaborative work. $55.6 \%$ of the students said they fully agree, $33.3 \%$ said they partially agree, $5.6 \%$ partially disagreed and $5.6 \%$ totally disagreed. At this point, it should be realized that a traditional perspective, in which each student works individually in the production of his knowledge, no longer suits the students' desire, since they demonstrate that working in a collaborative way is in their interest and that they do this without any problem. The fact that $11.2 \%$ of the students disagree about this perspective, can raise a hypothesis about aspects of personality or even relationships with the groups with which they carry out their work. However, this can and should be taken into account when planning the teaching process, since they must also be affected by educational actions.

In the last question, when asked whether the teacher should act as mediator of knowledge, $61.1 \%$ of the students said they fully agree, $33.3 \%$ partially agreed and $5.6 \%$ partially disagreed. The answer to this question reinforces the notion that learners understand the teacher as a fundamental figure in the process of teaching and learning, but do not perceive the educator as the absolute holder of knowledge. The fact that they consider it as a mediator points to the importance of the educator to decentralize their actions, seeking alternatives that contemplate the role of students in their learning.

From the answers presented in the instrument that analyzes and discusses the proposal of an innovative practice, as an active methodology, it is noticed that the students yearn for changes in the teaching and learning process. They feel the will to work in a collaborative way, using information and communication technologies (ICT) as allies to reinforce this process. More than this, they realize that it is fundamental that they are actively brought to participate in the construction of their own knowledge, because in this way this learning becomes significant.

The student, in an interactive teaching approach, presents greater autonomy and a greater degree of responsibility. With tasks to be performed, it is easier to expose, since there will always be time and space for the presentation of your ideas, being requested by the teacher and his colleagues - to position themselves, to expose their thinking and to take sides. Teaching activities with this level of participation can be carried out in environments that foster the interaction, collaboration and evaluation of students and teachers.

\section{References}

[1] [1] Abar, C.A.A.P., Barbosa, L.M. (2008) Webquest um desafio para o professor: uma solução inteligente para o uso da internet. São Paulo, SP: Avercamp.

[2] [2] Abud, K. M., Silva, A. C. M, Alves, R. C. (2010). Ensino de História. São Paulo, SP: Cengage Learning.

[3] [3] Bittencourt, C.M.F.(2008). Ensino de História: fundamentos e métodos. São Paulo, SP: Cortez.

[4] [4] Bittencourt, C.M.F. (2011). As "tradições nacionais"e o ritual das festas cívicas. In Pinsky, J. (Ed.). O ensino de história e a criação do fato. (53-92). São Paulo, SP: Contexto.

[5] [5] Dodge, B. WebQuests: a technique for internet: based learning. Distance Educator, 1(2), 1995. 10-13.

[6] [6] Freire, P. (2002). Pedagogia da Autonomia. São Paulo, SP: Paz e Terra.

[7] [7] Gomes, L. (2007). 1808: como uma rainha louca, um príncipe medroso e uma corte corrupta enganaram Napoleão e mudaram a História de Portugal e do Brasil. São Paulo, SP: Editora Planeta do Brasil.

[8] [8] Guimarães, M.L. S. (2011). Historiografia e Nação no Brasil (1838-1857). Rio de Janeiro, RJ: EdUERJ.

[9] [9] Horn, G.B., Germinari, G. D. (2006). O ensino de história e seu currículo. Rio de Janeiro, RJ: Vozes.

[10] [10] Kenski,, V. M.(2012). Educação E Tecnologias: O novo ritmo da informação. Campinas, SP: Papirus.

[11] [11] Lévy, P. (2007). O que é virtual? São Paulo, SP: Editora 34.

[12] [12] Miceli, Paulo. (2011). Uma pedagogia da História? In Pinsky, J. (Ed) 0 ensino de história e a criação do fato.(37 - 52) São Paulo, SP: Contexto.

[13] [13] Moran, J.M. (1995). Novas tecnologias e o reencantamento do mundo. Rev. Tecnol. Educ., 23(126), 2426. 
[14] [14] Pinsky, J. (2011). Nação e ensino de História no Brasil. In Pinsky, J. (Ed). O ensino de história e a criação do fato. São Paulo, SP: Contexto.

[15] [15] Ricupero, B. (2004). O Romantismo e a Ideia de Nação no Brasil (1830-1870). São Paulo, SP: Martins Fontes.

[16] [16] Rocha, L. R. (2007) A concepção de pesquisa no cotidiano escolar: possibilidades de utilização da metodologia webquest na educação pela pesquisa. (Master's dissertation). Retrieved from www.ppge.ufpr.br/teses/M07_rocha.pdf

[17] [17] Silva, M. (2000). Sala de aula interativa. Rio de Janeiro, RJ: Quartet. 